\title{
"Letter to Editor" Social Skills and Teamwork in New Generation of Nurses
}

\author{
*Akhtar Ebrahimi Ghassemi ${ }^{1}$
}

Effective teamwork is a critical element of a health workplace, but there are always challenges to meet the expectations of employers and workers. However, for the service-users in the health care setting is a requirement that they often presume to be in place. The duty of the policy makers, clinicians, and health system managers is to seek ways of improving the work conditions for workers and meeting patient expectations. In some countries, health system managers, policy makers, and educators are making major efforts to transform healthcare workplace into effective teamwork environments to achieve high-quality patient care with commitment toward integrative care. On the other hand, the continuous and rapid evolution of medical technology and the complexity of delivering patientcentered-care in the 21 st century calls for teamwork and collaboration among healthcare professionals. This article explores the importance of fostering social skills and teamwork in both clinical and teaching environments, and proposes some strategies to guide pedagogical perspectives to promote and strengthen effective teamwork environments through curricular changes in nursing and other health professions. The research and expert opinions offer a comprehensive overview of the benefits of teamwork and its implementation. To transform health care workplaces into effective team-based environment requires educational strategies for incorporating and promoting interprofessional collaborations in the health professions' curricula. Interprofessional education (IPE) is an ideal medium for introducing new knowledge to pre-professional students and healthcare professionals, and it is considered as an effective pedagogical means of improving collaboration. The World Health Organization (WHO) $)^{(1)}$ recognizes the need for collaboration among healthcare professionals in both education and clinical practice. Collaborative practice also involves working closely with patients, families, and communities to provide the highest level of patient care ${ }^{(2)}$. Using role-play or standardized patients in simulation labs allows pre-professional students to practice communication and decisionmaking skills necessary to work with patients and help them in their recovery journey. Educators wanting to incorporate IPE into their teaching and training strategies have several theories on which to draw. For example, sociocultural learning theory can be used as a lens through which to teach and evaluate team collaboration during students' IPE in clinical rotations or simulation labs. Nurse educators, nurse leaders, and nursing professionals can utilize high-impact practices and develop experiential-based strategies for enhancing teamwork and collaboration in new generation of nurses. High-impact practices encompasses classroom activities designed to promote learning, engagement, and completion of those activities in didactic and online courses. Collaboration and teamwork can be encouraged within assigned three-person study groups or through incorporating assignments with a community-based learning element requiring students to complete interviews with experts in the interdisciplinary healthcare team. Interprofessional education should be a major focus of university programs training future professionals to ultimately enhance the quality of patient care. Students who have participated in IPE, say it leads to increased knowledge of other disciplines and creates opportunities to consult with members of different professions ${ }^{(3)}$. As modern healthcare is delivered by multidisciplinary healthcare systems who rely on effective communication and teamwork to provide safe, efficient, and high- quality patient care, nurses in all specialty areas have countless opportunities to use their interpersonal skills to engage in collaboration and teamwork. To provide holistic, evidencebased, respectful attitudes toward patient-centered care and support, interprofessional education and collaboration are essential for health practitioners from different discipline backgrounds. It is crucial

\footnotetext{
1. Associate Professor, Department of Nursing, Hartwick College, New York, United States. (*Corresponding author) Email:aghassemi11@gmail.com;
} 
that nurse educators and nursing professionals take a firm stance in fostering social skills, teamwork, and the value of interprofessional collaboration in educating new generation of nurses.

Keywords: Nursing, Education, Teamwork, Social Skills, Students

How to Cite: Ebrahimi Ghassemi A. "Letter to Editor" Social Skills and Teamwork in New Generation of Nurses. Iran Journal of Nursing. 2019; 31(116):1-4.

Received: 3 Nov 2018

Accepted: 2 Feb 2019 


\section{"نامه به سردبير \\ مهارتهاى اجتماعى و كار تروهى در نسل جديد برستاران ليردير}

\section{'اختر ابراهيمى قاسمى'}

كار كروهى مؤثر عنصر اساسى محيط كار بهداشتى است و همواره جالشهايى براى برآوردن انتظارات كارفرمايان و كاركنان

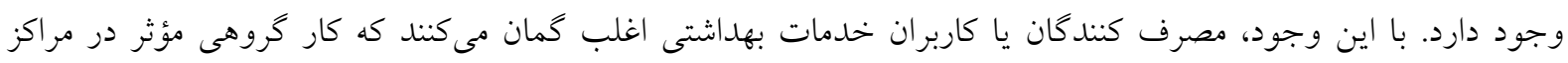
بهداشتى الزاما وجود دارد. وظيفه سياست كذاران، كلينيسينها و مديران نظام بهاشتى اين است كه راههايى براى بهبود شرايط كارى كاركنان و برآوردن

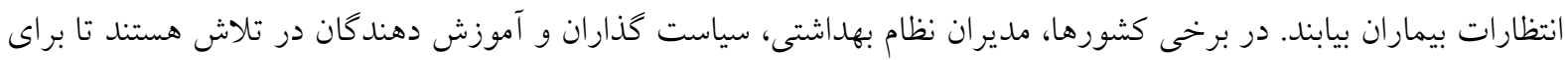

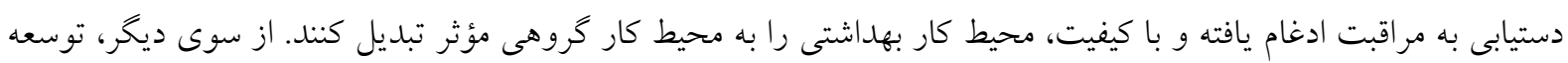

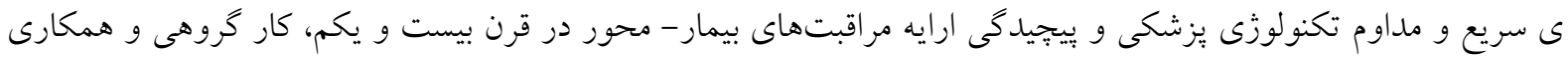

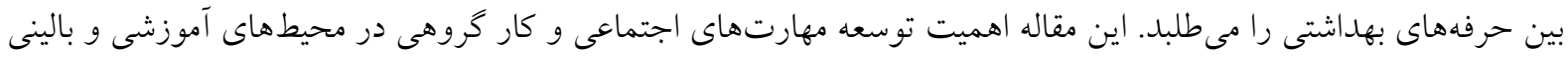

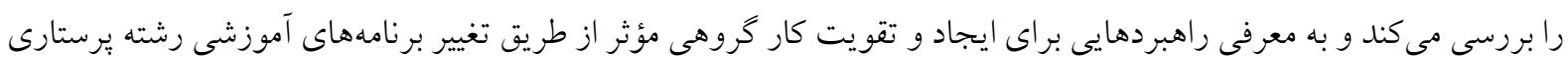

$$
\text { و ساير حرفهاى بهداشتى مى يردازد. }
$$

تحقيقات و نظرات متخصصين مرورى اجمالى از مزاياى كار گروهى و اجر آى آى آن ارايه مى كنند. براى تبديل محيط كار بهداشتى

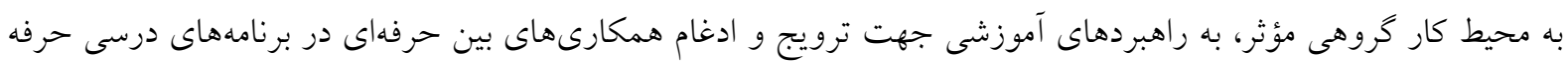

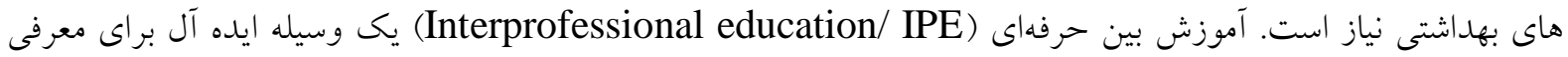
تازهاى دانش به دانشجويان و كاركنان مراقبتهاى بهاشتى است و به عنوان يكى ابزار آموزشى مؤثر براى بهبود همكارى

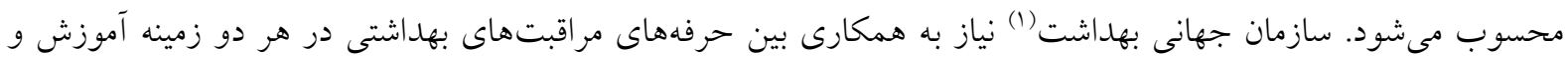

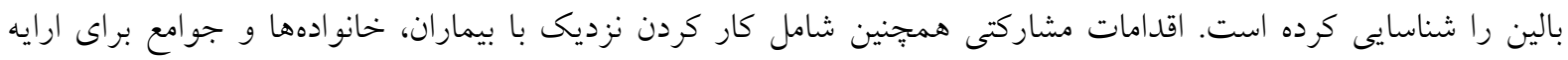

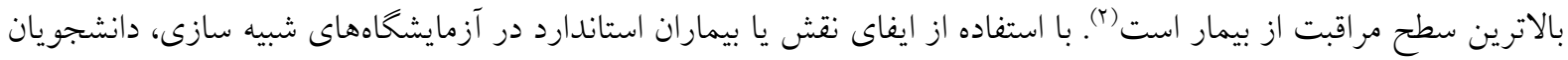

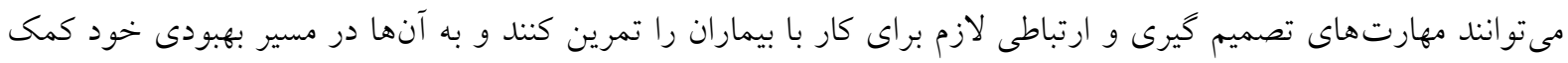

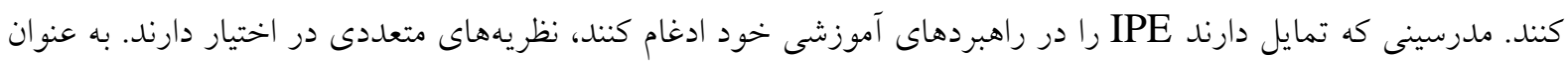

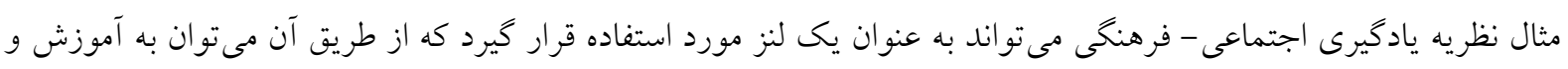

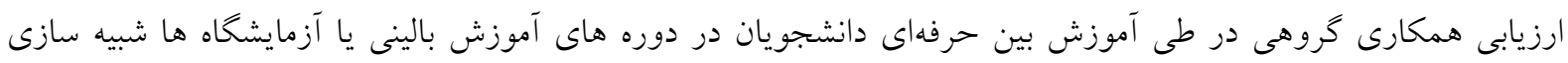

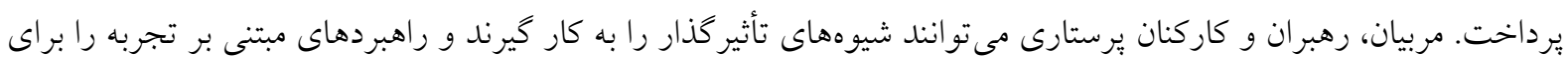

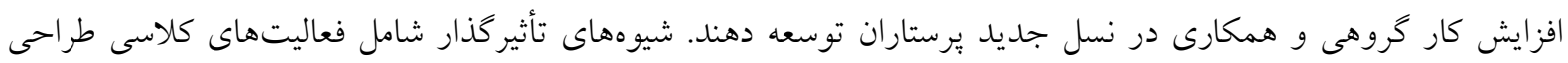

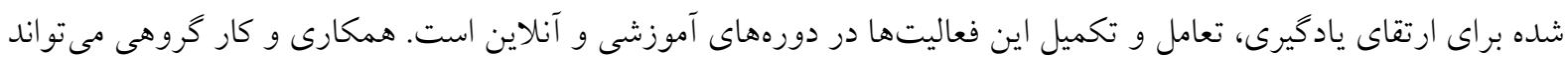

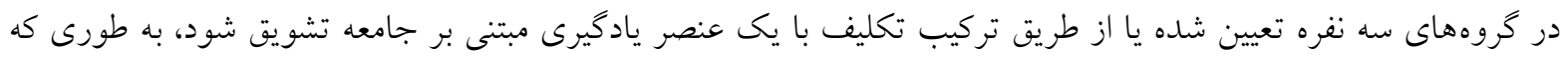

Email:aghassemi11@gmail.com . 
دانشجويان موظف به تكميل مصاحبههايى با متخصصين عضو تيم مراقبتهاى بهاشتىى بين رشتهاى شوند.

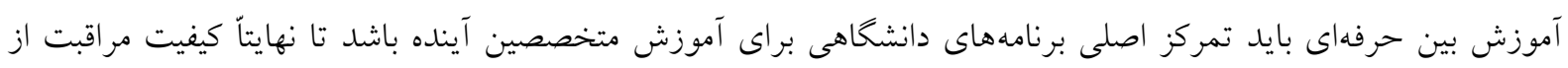

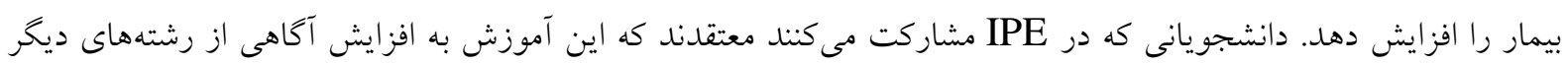

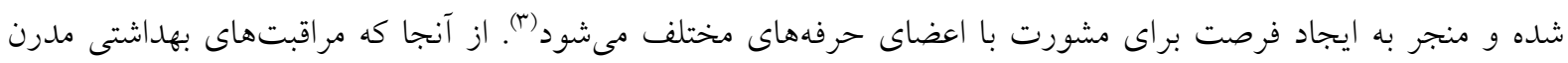

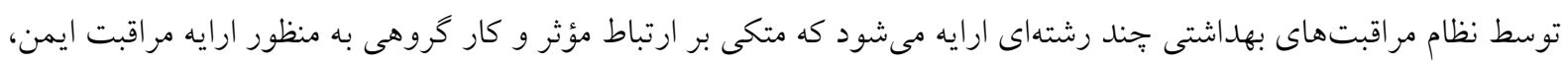

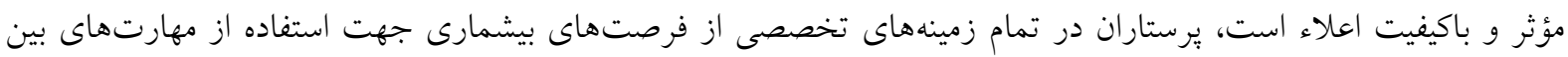

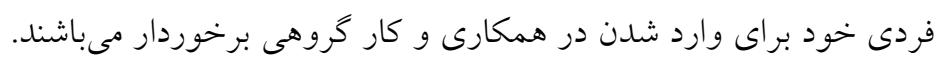

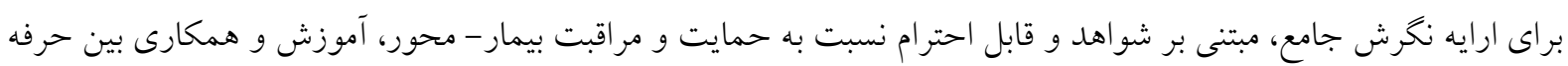

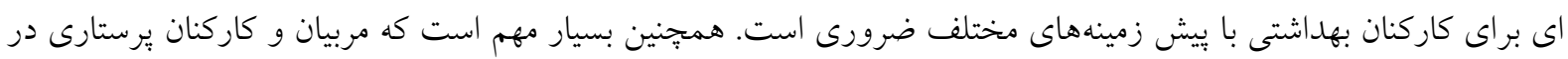

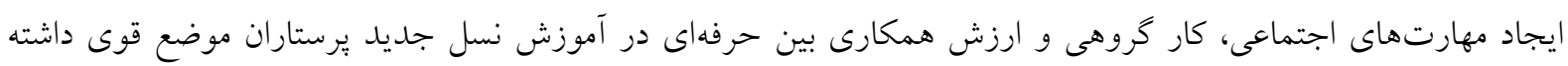

كليد وازٔهها: برستارى، آموزش، كار گروهى، مهارتهاى اجتماعى، دانشجويان تاريخ دريافت: تV/N/IT

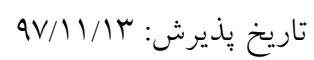

\section{References}

1. World Health Organization. Framework for action on interprofessional education and collaborative practice. Geneva: World Health Organization; 2010. Available from: http://www.who.int/hrh/ resources/framework_action/en/. accessed on 2016 Nov 02.

2. Dondorf K, Fabus R, Ghassemi AE. The interprofessional collaboration between nurses and speechlanguage pathologists working with patients diagnosed with dysphagia in skilled nursing facilities. J Nurs Educ Pract. 2016;6(4):17-20.

3. Baessler M, Best W, Sexton M. Beyond program objectives. J Contin Educ Nurs. 2016;47(6):2489. 